\title{
Enhancing People-to-People Cooperation between ASEAN and East Asia Countries through Counterparts: The Case of Indonesian Student in Taiwan
}

\author{
Paramitaningrum Tamkang University, Taiwan
}

\begin{abstract}
Besides businessmen and workers, Indonesian students have become one of the recent important actors in Indonesia - Taiwan bilateral relations. Currently, Taiwan became one of the popular destinations among Indonesians to pursue their highest degree. In 2013, the numbers of Indonesian students has reached 3000 persons, made them the third largest group of Southeast Asian students in Taiwan after Vietnamese and Malaysians. The Indonesian students are quite organized and active. Giving the lack of diplomatic relations between both countries, these students are potential to be one of the significant actors to bridge Indonesia Taiwan relations. However, they have some limitations on conducting their activities. On the Taiwan side, this trend has not gained sufficient responds. Indonesia is still considered an unattractive object to study, comparing to other Southeast Asian countries. Therefore interaction tends to be one side only. This paper would discuss on (1) what the Indonesian students in Taiwan can do to maximize their capabilities to attract Taiwanese to learn more about Indonesia; (2) How the Taiwanese should respond to these trends, in order to create two ways of interaction. In that case, the counterparts are significant to bridge the limitations of mutual interaction between both states, especially to eliminate the unclear perceptions among Taiwanese to Indonesia, which might affect Indonesia - Taiwan bilateral relations, and to promote Indonesia in the better outlook.
\end{abstract}

Keywords: Soft Power, actor, Indonesian Students, people-to-people interaction, counterparts, Indonesia-Taiwan

\section{Introduction}

Besides businessmen and workers, students have become one of the recent important actors in enhancing cooperation between ASEAN countries and their Pacific neighbours. Interaction among students and scholars from both sides is getting common.

Multiple channels of contacts facilitate interaction among students and scholars from both sides. The workshops on
Managing Potential Conflicts in the South China Sea, and Council for Security Cooperation in the Asia Pacific (CSCAP) are some examples of the multilateral forum which scholars from ASEAN countries can have interaction with their Asia Pacific counterparts, including Taiwan (Ku, 1998). Apart from that, several bilateral contacts between students and scholars from both regions are getting intensive. 
Indonesian students have become one of the recent important actors in Indonesia Taiwan bilateral relations. In the past few years Taiwan became one of the popular destinations among Indonesians to pursue their higher degree.

The numbers of Indonesian students are around 3000 persons in 2013 and it made Indonesians as the third largest group of Southeast Asian students in Taiwan after Vietnamese and Malaysians. Indonesian students are organised and active. There are several Indonesian students' organizations, which also promote Indonesian culture, in Taiwan.

Giving the lack of diplomatic relations between both countries, people-to-people interactions are the suitable way to bridge Indonesia - Taiwan relations. These students are likely to be one of the 'liaison officers' between both sides, although, they also have some limitations on conducting their activities.

On the Taiwan side, this trend has not gained sufficient responds. Indonesia is still as an unattractive object to study, comparing to Vietnam, the Philippines or Malaysia. Very little Taiwanese scholars and students learn about Indonesia. Therefore interaction tends to be one side only.

This paper discusses on (1) what the Indonesian students in Taiwan can do to maximize their capabilities to attract Taiwanese to learn more about Indonesia; (2) How the Taiwanese should respond to these trends, in order to create two ways of interaction. In that case, the counterparts from the Taiwan side are significant to encourage the interaction process. Therefore, it would strengthen people-topeople relations in Indonesia - Taiwan relations.

\section{Framework of analysis}

Actors play a significant role in international relations. Traditionally, state is always seen as the most important international relations actor. However, in the past two decades, the role of non-state actors, including individual in international relations is increasingly important. However, Papp (1988) argued that the role of individual in international relations is often difficult to determine because of the role that same individual may have head in an organisation, agency, or in government participating in international affairs. Therefore, an individual can play role is because of its own personal capability or its affiliation in certain institutions or both of them.

Furthermore, Papp (1988) explained that other types of private individual contacts also play definite but undocumentable roles in international affairs, such as student exchanges, foreign teaching $\&$ research, long term job-related migration or permanent settlement, and similar activities all yield personal level interactions between citizens of different countries. Individual can play diverse roles in contemporary international affairs and also play major roles in transmission of culture and values. Individual can also involve in policy formulation and implementation, and even in economic affairs. The Indonesian students are categorised as an 'individual actors' of international relations, because they migrate to other countries, interact with local people and other people from different countries. They also promote Indonesian culture, in the place where they stay.

Due to the lack of diplomatic relations between Indonesia and Taiwan, the interactions between both countries are focused more on non-political issues, such as economic and social-culture. These states (both Indonesia and Taiwan) are still the 
main actors but both have limitation to do its function. As a result, non-state actors also have to be involved. Indonesian students, with other non-state actors, such as Indonesian workers, Indonesian spouses and Indonesian businessmen are expected to support state actors on doing such relations. Apart from economic activities, social-cultural activities are the supporting component, which facilitates people-topeople interaction.

Furthermore, when people-to-people interaction is implemented, the soft power is also applied. Soft power is the ability to get what you want through attraction rather than coercion or payments. It arises from the attractiveness of a country's culture, political ideals, and policies (Nye, 2004). Nye further added "When our policies are seen as legitimate in the eyes of others, our soft power is enhanced". The soft power of a country depends on three resources: its culture (in places where it is attractive to others), its political values (when it lives up to them at home and abroad), and its foreign policies (when they are seen as legitimate and having moral authority). Therefore, people from a particular country promote their soft power in their interaction with people from other countries. Through social and cultural activities, they introduce their own values through their culture, attitude and performance. In the level of state-to-state relations, a country will do the same like the ordinary people do, but their action is described through its foreign policy and its stance on international affairs.

Soft power would call of people's attention if the ideas are unique and adjustable with to the prevailing global norms (for instance multiculturalism and pluralism). Besides, the multiple channel of communication is significant to deliver the ideas. For that reason, state and non-state actors should work together. Meanwhile, the interaction between states actors in international relations somehow has not been enough, due to some limitations (e.g. national priorities, lack of diplomatic relations). Therefore another official mechanism to back up the interaction, who involves non-state actors, is needed.

Currently, such interactions which involve state and non-state actors are common. In this paper, Indonesian students and their efforts on promoting Indonesia can be categorised as soft power because they represent Indonesia and try to make other people feel attracted and would like to get to know more about Indonesia for the sake of those people' interests. These students are categorised as the non-state actors because they are considered as nonsovereign entities that exercise significant economic, political, or social power and influence at a national, and in some cases international level. ${ }^{1}$ These students represent Indonesia but they are ordinary citizen, not government officials. Therefore, they are more flexible on having interaction with people across border, refers to Josselin and Wallace said that the non-state actors are not fully autonomous from central government funding and control, but they are participating in networks which extend across the boundaries of two or more states -thus engaging in 'transnational' relations (Josselin and Wallace, 2001).

Being young scholars in a foreign country, these students are also concerned about how to improve Indonesia to be a better country and shared their thoughts through internal and external academic forums. There are two main frameworks through which the world of scholars intersects with the world of policy which can accommodate them. The first is "epistemic communities," which is a network of professionals with recognised

\footnotetext{
1 "Non-State Actors: Impact on International Relations and Implications for the United States," accessed at http://www.fas.org/irp/nic/nonstate_actors_2007.pdf
} 
expertise and competence in a particular domain and an authoritative claim to policy-relevant knowledge within that domain or issue-area. (Haas, 1998). The professionals may be from a variety of discipline and backgrounds but are bound by shared normative and causal beliefs, shared notions of validating knowledge claims, and "a set of problems to which their professional competence is directed, presumably out of the conviction that human welfare will be enhanced as a consequence."

The second is "track-two dialogue" which means "unofficial policy dialogues focused on problem solving in which the participants have some form of access to official policymaking circles" (Kaye, 2007). Wanandi further added that track two involves the participation of government officials in a private capacity, a principle that supposedly allows for free discussion and flexibility (Wanandi, 1995). Acharya also explained how epistemic communities and track-two forums may impact on policy. The first is through policy innovation, or generation of new policy ideas. The second is the "constitutive localisation", whereby local actors proactively build congruence between global norms and preexisting local ideas and practices. As part of this, they may serve as "filtering" mechanism for approaches to cooperation developed in other parts of the world so as to make them locally applicable. Thirdly, epistemic communities and track-two dialogues also serve as platforms for validation and legitimization of the ideas and policies of governments. Fourthly, they can generate dissent; which while not be to the liking of policymakers, alerts them to alternative ideas and approaches out there in terms of which their own preferences will be benchmarked and assessed (Acharya, 2011). The epistemic community may have different opinion and stance with the policymakers, and both sides recognise it.
Despite of such differences, the epistemic community' opinion will still be acknowledged publicly.

\section{A brief overview about Indonesia}

Indonesia is an emerging regional power, which has attractive physical and non-physical modalities. The Republic of Indonesia is the largest archipelagic state in the world, located in Southeast Asia. Its size is 1.919.440 square kilometres. Indonesia is situated in the equator between the Asian and Australian continents and between the Pacific and Indian Oceans.

Indonesia consists of 18,000 islands with population around 251,160,124 million. ${ }^{2}$ This made Indonesia the fourth largest populated country in the world, after China, India and the USA in 2012. ${ }^{3}$ These facts made Indonesia as one of the significant countries in Southeast Asia because its population is almost half of total ASEAN population.

Indonesia is an emerging economic powerhouse in Southeast Asia. Economic annual growth rate is about $6.23 \%$, little bit lower than in 2011, which reached 6.5\%. Indonesian per capita GDP has reached \$ 3495 (2011). ${ }^{5}$ It is reported that Indonesia has 45 million members of the consuming class, 55 million skilled workers, and $\$ 0.5$ trillion market opportunity in consumer services, agriculture and fisheries, resources, and education (McKinsey, 2012). It is also understandable because around $42.2 \%$ of Indonesian population is in the

${ }^{2}$ Based on the estimation of CIA the World Fact book (July 2013), retrieved

https://www.cia.gov/library/publications/the-worldfactbook/geos/id.html

${ }^{3} \mathrm{http}: / / \mathrm{www}$.indexmundi.com/g/r.aspx? $\mathrm{v}=21 \& \mathrm{t}=20$

${ }^{4}$ Indonesia's Economic Growth Slows, The Wall Street Journal, February 5, 2013, accessed in http://online.wsj.com/article/SB1000142412788732444590457 8285081322220700.html

${ }^{5}$ http://data.worldbank.org/indicator/NY.GDP.PCAP.CD 
productive age (25-54 years). ${ }^{6}$ That means Indonesia is developing its capacity to strengthen its position as an emerging power.

Furthermore, Indonesia' long process development to be a democratic country is remarkable. In the level of state-to-state interaction, the participation in ASEAN, East Asian Summit (EAS) and G-20 forum is good indicator to show that Indonesia is an active player. In other words, Indonesia prefers to work together, instead of being a solo player. Nevertheless, not all Indonesians enjoyed their countries achievements. Non-state actors have not been more involved, since the opportunities are still limited.

After Indonesia had political turbulence in 1998, the domestic condition is changed. Indonesia encountered a transition from an authoritarian to the democratic country. Within a democratic order, state is still an important actor but non-state actors started to play important role in the Indonesia political arena. This means people aspiration and views can be no longer being ignored. Therefore Indonesian foreign policy should be re-formulated also to accommodate such condition.

According to Sukma (2011), the confluence of democracy \& moderate Islam - described as assets of foreign policy and construed as key elements of soft power has become an important element of Indonesia's foreign policy and public diplomacy since 2002. However, he also recommends these two things (democracy and moderate Islam) should be better constructed to be the value to create Indonesia's image in the world. Although it has not been completely perfect, Indonesia is seen as a role model for building democracy and pluralism. Bali Democracy Forum and The Interfaith Dialogue Forum help Indonesia to project its international posture. Such abovementioned modalities and achievements made Indonesia have enough capacity to raise its soft powers.

Those two abovementioned events were organised by Indonesian Ministry of Foreign Affairs. This institution so far is the main actor to promote Indonesian soft power. Since 2002, the Ministry of Foreign Affairs had internal reform program and adjust its foreign policy machinery, in order to meet the new challenges in Indonesia post-authoritarian government.

After Indonesia had transformation from authoritarian to democratic government, Ministry of Foreign Affairs started to hold several events to invite nonstate actors. These are aimed to gain some valuable input for Indonesian foreign policy strategy.

In addition to that, Indonesia has tremendous numbers of human resources to promote its soft power. The biggest number of Indonesian population is in the productive age (25-54 years old). Some of them live in the foreign countries, as students, foreign workers, and immigrant spouses. The number of Indonesians studying abroad is between to 40.000 to 50.000 (British Council 2010). ${ }^{7}$ Australia, U.S, the UK and Singapore were the most desirable destination for Indonesians.

They have several reasons to study abroad such as gaining the better education environment, increasing the horizon, the future jobs opportunities, improving foreign language skills, and train the personal maturity and independence. Recently, Japan, Korea, Malaysia and Taiwan become the popular destination to study, because of those abovementioned reasons, the quality of education in such

\footnotetext{
${ }^{7}$ http://www.britishcouncil.org/eumd-information-

background-indonesia.htm. Also see, “Vice Minister of National Education, Fasli Jalal, said now the number of Indonesian students abroad reached 40,000 people," Seputar Indonesia, 19 January 2010, http://www.seputarindonesia.com/edisicetak/content/view/298794/1/
} 
countries, and the geographical location. In addition to that, those countries also provide scholarships for International students. This is also another triggering factor to attract Indonesians study to study there.

\section{Indonesian students in Taiwan}

Taiwan is an interesting case study. Since there is no diplomatic relations with Indonesia, the relation between both sides is focused more on non-political issues. Trade is the main activities, followed by cooperation in the field of economy, agricultural, health and education. Besides Indonesian businessmen and workers, Indonesian students also become one of the recent important actors in Indonesia Taiwan bilateral relations.

As it is seen in the table 1, the numbers of Indonesian students are increasing in the past few years. The table shows that until 2012, Indonesians are the third largest group of foreigners studying in Taiwan after Vietnamese and Malaysians. The Indonesian students in Taiwan are consisted of the students of Mandarin language programs and non-language programs or degree seeking programmes (undergraduate and graduate level).

The non-language program students are mostly majoring in engineering, technology and businesses management. Recently, studying in Taiwan becomes much more popular, since Taiwan government offered several kinds of scholarships for International students since 2004. ${ }^{8}$ In

\footnotetext{
${ }^{8}$ Five government agencies (Ministry of Education (MOE), Ministry of Foreign Affairs (MOFA), Ministry of Economic Affairs (MOEA), National Science Council of the Executive Yuan (NSC) and ICDF (International Cooperation and Development Fund) ---have jointly established the Scholarship Program of Taiwan to encourage outstanding international students to undertake degree programs in Taiwan. See
}

addition to that, Taiwan government has bilateral Memorandum of Understanding (MOU) with the Government of Aceh Province, to give scholarships for a number of Indonesian students from Aceh to study postgraduate in Taiwan. Meanwhile, several universities in Taiwan also proactively recruit students from several universities in Indonesia.

As a result, several Indonesian universities now also have several kinds of cooperation with universities in Taiwan, such as offering double degree and sandwich programme. ${ }^{9}$ In addition to that Taiwan Higher Education Fair is annually held in several big cities in Indonesia. In 2011, Taiwan Education Center (TEC) is established in Surabaya, East Java. ${ }^{10}$

Recently, Indonesian Ministry of Education also provided many kinds scholarships for Indonesian teaching staffs to pursue their higher academic degree abroad and some of them also choose Taiwan. ${ }^{11}$ Here, interactions between both countries are increasing to enhance cooperation on education sector.

http://english.moe.gov.tw/ct.asp?xItem=6798\&CtNode $=1063$ $\underline{2 \& m p=1}$

${ }^{9}$ National Taiwan University of Science and technology (NTUST) and National Pingtung University of Science and Technology (NPUST) are one of Taiwan universities have double degree program with University of Brawijaya in Malang and Institute of Technology Sepuluh November (ITS) in Surabaya. Both Brawijaya and ITS are located in East Java, Indonesia.

${ }^{10}$ TEC is a non-profit organisation, funded by Taiwan Ministry of Education and aimed to promote higher education in Taiwan and strengthen bilateral academic exchange between Taiwan and Indonesia. TEC Official Website "About TEC" Retrieved in February 14 2014 from http://portal.tecindonesia.com/?page id=13\&lang=en. ${ }_{11}$ This scholarship program is managed under Program Beasiswa DIKTI or the Directorate of Higher Education' Scholarship Program 
Table 1 Number of ASEAN Student in Taiwan

\begin{tabular}{|c|c|c|c|c|c|c|}
\hline $\begin{array}{c}\text { Year } \\
\text { Country }\end{array}$ & 2008 & 2009 & 2010 & 2011 & 2012 & 2013 \\
\hline $\begin{array}{c}\text { Brunei } \\
\text { Darussalam }\end{array}$ & - & - & - & - & - & - \\
\hline Cambodia & 24 & 14 & 6 & 8 & - & - \\
\hline Indonesia & 2281 & $\mathbf{2 2 7 5}$ & $\mathbf{2 2 7 4}$ & $\mathbf{2 4 7 2}$ & $\mathbf{2 7 2 3}$ & $\mathbf{3 2 0 0}$ \\
\hline Laos & - & - & - & - & - & - \\
\hline Malaysia & $\mathbf{1 0 0 1}$ & $\mathbf{1 5 6 0}$ & $\mathbf{1 9 6 1}$ & $\mathbf{2 2 8 6}$ & - & - \\
\hline $\begin{array}{c}\text { Myanmar/Bu } \\
\text { rma }\end{array}$ & 47 & 33 & 17 & 17 & - & - \\
\hline Philippines & 302 & 313 & 292 & 336 & - & - \\
\hline Singapore & 67 & 103 & 99 & 102 & - & - \\
\hline Thailand & 549 & 637 & 760 & 848 & - & - \\
\hline Vietnam & $\mathbf{1 7 7 9}$ & $\mathbf{2 5 9 2}$ & $\mathbf{3 2 8 2}$ & $\mathbf{3 6 8 7}$ & - & - \\
\hline Sources: from & & & & & & \\
\hline
\end{tabular}

Sources: from various sources

Besides scholarships offers, there some other factors influence Indonesian to choose Taiwan to be their study destination: (1) Taiwan is only a short distance from Indonesia; (2) Taiwan expertise on science and technology also can meet Indonesians lack of competence; (3) Taiwan also becomes a favourite place for Indonesians who wants to improve their Mandarin language skills. Those factors, categorised as 'push and pull' factors by Mazzarol and Soutar (2002), attracted Indonesian students and increased the number of them in Taiwan.

\section{Indonesian Students organisations in Taiwan}

There are three Indonesian students' organizations: PERPITA, FORMMIT, and PPI-Taiwan. PERPITA (台灣印尼僑生聯誼會 ) is an abbreviation from Persatuan Pelajar Indonesia di Taiwan. It was established in 1960 in National Cheng Kung University (NCKU) with 35 members.
This organization aimed to help Indonesian students to gain and exchange information about studying and living in Taiwan and to facilitate Indonesian students to get together. The establishment of PERPITA also obtained support from 僑委 會 or Organization of Overseas Compatriot Affairs Commission (OCAC) and 印尼歸僑 協會 (Indonesian Overseas Chinese Association). Until the year 2001, the memberships of PERPITA reached to 800 students.

FORMMIT (Forum Mahasiswa Muslim Indonesia di Taiwan) or Indonesian Moslem Student Forum in Taiwan (台灣印尼學生穆 斯林論壇) is established in 2006 in Taichung. It is aimed to maintain relationships between Indonesian Muslim students in Taiwan and to become a forum of gaining and exchanging skills and experiences among Indonesian Moslem students.

The number of FORMMIT members roughly is 130 students, spread out from Northern to the Southern of Taiwan. 
FORMMIT has regular and special activities. Regular activities are mostly concentrated to the religious activities, such as reciting Al Qur'an together and listening to religious lecture by a cleric. But FORRMIT members also has special programmes, such as teaching some skills such as Computer and Basic accounting, conducting workshop on entrepreneurships for Indonesian workers, and having a regular scientific discussion about the current issues with Indonesian and Taiwanese experts.

FORMMIT also have an annual special activity, the Annual Indonesian Scholars Conference in Taiwan (AISCT). It had been held three times, and had various topics from economic, agriculture and information and communication technology. AISCT was attended by Indonesian scholars from Indonesia, Singapore, Japan and the Indonesian students in Taiwan.

PPI Taiwan (Perhimpunan Pelajar Indonesia di Taiwan - 台灣印尼學生聯合會) or Indonesian Student Association in Taiwan is established in the 2nd of May 2010, in the commemoration of Indonesian National Education Day, in Chung Yuan Christian University, Chungli. This organization is also aimed to gather Indonesian students in Taiwan and to play some role on developing Indonesian human resources by encouraging Indonesian students to study and to learn some skills, to develop their personal capacity.

PPI Taiwan mostly cooperates with other PPI in the university levels, when these organizations conducted some activities. ${ }^{12}$ There are some examples of

12 Several universities in Taiwan, which has around 15-300 students, such as National Taiwan University of Science and Technology (NTUST), National Cheng Chi University (NCCU), National Cheng-Kung University (NCKU), National Central University (NCU), National Dong Hwa University (NDHU), National Pingtung University of Science and Technology (NPUST), Chung Yuan Christian University (CYCU), Chinese Culture University (CCU), Asia University, established Indonesian Student Association in these partnerships such as giving some support to several PPI in the university level, which held Indonesian Cultural Events, or academic conferences, and they work together on making a serial 'Lentera Ide', about the life of Indonesian students or non-students in Taiwan. PPI Taiwan also has some other related student activities. ${ }^{13}$

One of their latest and current activities is to cooperate with Indonesian Economic and Trade Office in Taipei, to run Taiwan branch of Indonesia Open University (Universitas Terbuka - Taiwan or UTTaiwan). This university was opened in 2011 in Taipei.

Currently, Universitas Terbuka - Taiwan has about 100 students, who are mostly Indonesian workers in Taiwan, tutored by Indonesian students, who are pursuing their graduate studies in Taiwan. Previously, Universitas Terbuka already had opened its branches in Saudi Arabia, Singapore, Malaysia, Hong Kong and South Korea.

In April 2012, The First Taiwan Indonesia Higher Education Summit was held in Taipei. This is the second high level meeting between Indonesia and Taiwan to discuss about education. The first one was held in Bali in 2011, while Indonesia and Taiwan signed An Agreement of Cooperation in the Field of Higher Education.

Under this umbrella agreement, the cooperation between both countries are enhanced in several items, such as scholarships programme, academic matters (double degree, credit transfers, bridging programmes for Indonesians, who will attend $\mathrm{PhD}$ programme in Taiwan) and research collaboration. The last Taiwan Indonesia Higher Education Summit in Bali

their school. These organisations are affiliated with PPI Taiwan.

13 One of the example is helping and coordinating Indonesian students to buy flight ticket to go back to Indonesia, 
in 2013 concluded that both sides agree to establish networks. ${ }^{14}$

All those abovementioned examples show that Indonesian students are quite active. Besides studying, the Indonesian students' activities also prove that they made positive contribution to their fellow Indonesians. These students are concerned on how to make use of their knowledge and living experience in Taiwan and how those things can be applicable in Indonesia. During their interaction with the Taiwanese people, they promote Indonesian multiethnic culture, Indonesian language, attitudes and values.

As a result, the Taiwanese are better informed that Indonesia is not only big in term of size but also its population. They know that Indonesia has many more islands instead of Bali, and many ethnic groups. Therefore, Indonesian culture is very rich, in terms of arts, food, outfit, and customs. Some Indonesian students teach Indonesian language (Bahasa Indonesia), formally or informally, to their friends or their professors. They wear Batik and other Indonesian traditional outfits in several occasions. Gradually, these students promote Indonesian language and culture to the Taiwanese society.

Despite of their good achievements on promoting Indonesia, these Indonesian students have limitations. The first is time constraint. As a student, they have to prioritise studying and other related works.

As a result they only have limited time to do some other things. Secondly is status constraint. Most of Indonesian students are scholarship recipients. Therefore, they are

\footnotetext{
14第2屆臺灣印尼高等教育論壇與臺灣高等教育展成果豐碩 (The $2^{\text {nd }}$ Taiwan and Indonesia Higher Education Summit and the Taiwan Higher Education are Fruitful). Retrieved in http://www.edu.tw/pages/detail.aspx?Node=1088\&Page $=214$ 04\&wid=409cab38-69fe-4a61-ad3a-5d32a88deb5d\&Index=1
}

not supposed to do other works which are not related to their study. If they want to do other work, they should meet some requirements, such as providing a proof that they are currently not Taiwan scholarships recipients and having a work permit for foreign students. Based on such limitations, these Indonesian students are not able to allocate their time and commitment professionally to promote Indonesian culture within their environments.

At the same time, Indonesian Economic and Trade Office in Taipei (IETO) or Kantor Dagang and Ekonomi Indonesia di Taipei (KDEI - Taipei), also have limitations to promote Indonesia. IETO/KDEI, which also becomes an Indonesian representative office in Taiwan, does not have a special official, who is fully responsible for information and cultural affairs. Therefore they also could not do their function completely. From the government side, Indonesia has not been able to raise its high profile in Taiwan on cultural affairs.

On the Taiwan side, this recent development on Indonesian students has not gained sufficient responds. Indonesia has being seen as an unattractive object to study, comparing to Vietnam, Philippines or Malaysia. There are still small numbers of research about Indonesia done by Taiwanese scholars, and only few Taiwanese scholars understand Indonesia and its complexities.

In Taiwan, there are only two universities has a graduate school of Southeast Asian Studies, but they do limited study on Indonesia. ${ }^{15}$ In other words, Indonesia is still a marginalised study object among students and scholars in Taiwan universities.

\footnotetext{
15 There are two Taiwan universities which has a Graduate School of Southeast Asian Studies: National Chi Nan University (a state university) and Tamkang University (a private university). In Tamkang University, Southeast Asian Studies is a sub-division of the Institute of Asian Studies.
} 
In general, there is still lack of comprehensive information about Indonesia among Taiwanese, as it is explained by the Head of Taipei Economic and Trade Office (TETO), Ambassador Andrew Hsia. ${ }^{16} \mathrm{He}$ explained that only a few Taiwanese knows that Indonesia now is a democratic country with good political and social stability. But most of them still tend to think that Indonesia as a part of Bali Island and/or as a migrant workers exporting country. This kind of perception and their partial understanding made Indonesia a less important country, in Taiwan, compared to other Southeast Asian countries.

Furthermore, Taiwan government is still lack of approach on how to engage Indonesian students, in the professional way, such as how to make use of these students availability in Taiwan and how to accommodate their skills, knowledge and expertise to enrich Taiwanese understanding about Indonesia. Indonesian students, like other International students are still viewed only as a scholarship recipient although some of them have been working as a professional in their field. If Taiwan government is aware of the potency of Indonesian students, their presence can be a bridge between Taiwan and Indonesia relations.

Language barrier probably becomes the main obstacles for the Indonesian students to mingle with the locals. Most of them have limited skills on Chinese language, except the ones, who study Chinese language. At the same time, most Taiwanese people still have strong tendency to think that all foreigners should have ability to speak and read Chinese, when they are in Taiwan. Given the fact that

16 "Taiwan and Indonesia to Enhance Economic Relations", The President Post, March, 02, 2013. Retrieved April 2, 2013 from http://www.thepresidentpost.com/2012/03/02/taiwanand-indonesia-to-enhance-economic-relations/.
Indonesian workers are much more fluent in speaking Chinese and even Taiwanese, this problem may affect the Indonesian students' daily interaction with the local Taiwanese people. As a result, this barrier may affect the students' efforts to promote Indonesian culture and to have access to the local community to do such things.

\section{Some initiatives to promote people-to- people interaction}

However, there are some breakthroughs by some Taiwanese academicians in order to manage such abovementioned obstacles. Firstly, there are two annual conferences which have a special panel on Indonesian development. First panel is held in the Annual Conference of Taiwan Association of Southeast Asian Studies (TASEAS) at the each of 2012 and 2013.

The panel, initiated by Prof. Ching-lung Tsay from Institute of Asian Studies, Tamkang University, discusses about Indonesian development. Second panel about Indonesia is held in International Conference on Asia Pacific Studies (ICAPS) in National Sun Yat Sen University at the each of 2012 and 2013. ${ }^{17}$

Several Indonesian young scholars were invited to join those panels, which are aimed to promote Indonesia as one of appealing object to study and to build collaboration between Taiwanese and Indonesian scholars.

Secondly, since September 2013, Institute of Asian Studies, Tamkang University offers a course, "The Rise of Indonesian Economy and its implications for Taiwan and Japan." The main idea of this course is to the study the Master Plan Percepatan, Perluasan, dan Pembangunan

\footnotetext{
17 For information about International Conference on Asia Pacific Studies, 2012 and 2013, in National Sun Yat Sen University, Kaohsiung, Taiwan, can be seen in http://icaps.nsysu.edu.tw/files/11-1122-7648.php
} 
Ekonomi Indonesia or MP3EI (the Master Plan for the Acceleration and Expansion of Economic Development of Indonesia) and the rise of Indonesian Economy and how these phenomenon implies Taiwan and Japan. Initiated by Prof. Ching-lung Tsay (Institute of Asian Studies, Tamkang University), this is the first formal intellectual forum in Taiwan for expert lecturing, class discussions and professional interactions among Taiwanese and Indonesian specialists on specific issues of Indonesian economic development.

Taiwanese and Indonesian students took this course. They are taught by Prof Ching-lung Tsay and other Taiwanese senior and junior scholars, and some Indonesian experts. The two panels in TASEAS and this course are under the Program Collaboration between Indonesia and Taiwan (The CINTA Program). This initiative is also aimed to promote mutual interaction among scholars and professionals from Taiwan and Indonesia.

Those above-mentioned case studies showed that each side works step by step to use soft power to establish epistemic community for Indonesian studies. However, it will be much better if such activities done by Indonesian and Taiwanese scholars received proportional attention from the Taiwan side. Establishing a so-called a counterpart from the Taiwan side, to accommodate will be a good step.

This counterpart can be in the form of forum or association, who works on Indonesian issues. Any Taiwanese, either they are students, academician, businessmen, artists, or ordinary people, which have any interests about Indonesia and Indonesia - Taiwan relations, can join this forum or association. They can share their knowledge and experience each other. This forum or association would be the bridge between Indonesia and Taiwan and support Indonesian - Taiwan relations.
Refers to the previous explanation about epistemic community and second track diplomacy, this 'counterpart forum or association' can support the current activities of $2^{\text {nd }}$ track dialogue and epistemic community between Indonesian and Taiwan, if any.

Since epistemic community and $2^{\text {nd }}$ track dialogue usually has privileges to the government access, the 'counterpart forum or association' can be invited to be involved in the decision making policy. It is expected that their contribution can improve Indonesia - Taiwan bilateral relations.

\section{Conclusion}

Giving the lack of diplomatic relations between Indonesia and Taiwan, both countries should be creative to minimize this gap. People-to-people interaction is the suitable way to bridge Indonesia - Taiwan relations. In this case, the state actors on both sides have some limitations to do the function as normal bilateral relations always work.

Therefore, state actors should give significant support to people-to-people interaction and facilitate them. Indonesia should assign an official who is fully in charge on culture and education affairs in IETO/KDEI, to help Indonesian students and scholars efforts to have interaction with their Taiwanese counterparts, and to establish an epistemic community between both countries. Taiwan government is strongly suggested to do similar one.

Furthermore, Indonesian students are potential to bridge Indonesia - Taiwan relations. Although their number is much smaller than Indonesian workers ${ }^{18}$, they are potential to help raising Indonesian soft power. Education became a media to share

\footnotetext{
18 The number of Indonesian workers in Taiwan reached 205.213 (2013). These workers mostly work as a caregivers and fishermen. It made Indonesia as the biggest Southeast Asian migrant sending country in Taiwan (44\% among total number of Southeast Asian migrant workers in Taiwan).
} 
and exchange their knowledge, skills and experience with the Taiwanese local people in their school and place to stay, and to mingle with them.

Although, it has not gained enough response from Taiwanese society, Indonesian students send a message to Taiwanese society about their positive achievements and help Taiwanese society to understand more about Indonesia and the diversity of Southeast Asia. These interactions rely on the students' selfpotential and it creates an opportunity to expand the networking among them.

These are useful for the students will be the professionals in their own fields and become the future leaders of Indonesia. This kind of interaction is less politically constrained then it should be more enhanced.

In sum, Indonesia and Taiwan still needs to work hard to maximise their bilateral interaction. The good strategy and collaboration between state and non-state actors in both sides still needs to be improved.

Here the 'counterpart forum or association' is significant to bridge the limitations of bilateral interaction between both states, especially to eliminate the unclear perceptions among Taiwanese to Indonesia, which might affect Indonesia Taiwan bilateral relations, and to promote Indonesia in the better outlook.

\section{About the Author}

Paramitaningrum is a $\mathrm{PhD}$ Candidate at the Graduate Institute of European Studies, Tamkang University, Tamsui, Taiwan. She is one of the recipients of the Taiwan Scholarships from Taiwan Ministry of Education in 2008. She can be contacted at paramita.sp@gmail.com.

\section{References}

Acharya, A. (2011). Engagement or Entrapment? Scholarship and Policymaking on Asian Regionalism. International Studies Review, 13: 12-17

CIA the World Fact book (July 2013). Retrieved in February 11, 2014 from https://www.cia.gov/library/publications/th e-world-factbook/geos/id.html

Haas, P.(1992). Epistemic Communities and International Policy Coordination, International Organization, 46:3

Josselin, D \& Wallace, W. (eds.). (2001). Non-State in World Politics, Hampshire: Palgrave. p.3-4

Ku, Samuel C.Y. (1998). Taiwan's Diplomatic Maneuvers in the Asia Pacific: A perspective of Complex Interdependence, Issues and Studies 34 (6) 80-97

Mazzarol, Tim \& Geoffrey N. Soutar. (2002). "Push-pull" factors international student destination choice, The International Journal of Educational Management, 16 (2): 8290

Joseph S. Nye, Jr. (2004). Soft Power: The Means to success in World Politics, New York: Public Affairs.

Kaye, Dalia Dassa. (2007). Talking to the Enemy: Track Two Diplomacy in the Middle East and South Asia. Arlington. VA: RAND Corporation.

Papp, Daniel S. (1988). Contemporary International Relations: Framework for Understanding, $2^{\text {nd }}$ Edition. London: Macmillan Publishing Company. P. 93-95

Sukma, Rizal. (2011). Soft Power and Public Diplomacy: The Case of Indonesia. in

Jan Melissen and Sook Jong Lee (eds), Public Diplomacy and Soft Power in East Asia, New York: Palgrave-Macmillan.

Wanandi, Jusuf. (1995). The Regional Role of "Track Two" Diplomacy: ASEAN, ARF, and CSCAP, Japan Review of International Affairs, 9: 155-168

"Non-State Actors: Impact on International Relations and Implications for 
the United States," accessed at http://www.fas.org/irp/nic/nonstate actors 2007.pdf

CIA the World Fact book (July 2013), retrieved in https://www.cia.gov/library/publications/th e-world-factbook/geos/id.html

Indonesia's Economic Growth Slows, The Wall Street Journal, February 5, 2013, accessed in http://online.wsj.com/article/SB10001424127 887324445904578285081322220700.html

"The Archipelago economy: Unleashing Indonesia's potential," September 2012, Retrieved in October 1st, 2012 in http://www.mckinsey.com/insights/asiapacific/the archipelago economy

http://portal.tecindonesia.com/?page_id $=13 \&$ lang=en in February $14^{\text {th }} 2014$.

2013印尼臺灣高等教育展 圓滿落幕

(2013 Indonesia and Taiwan Higher Education Fair was over succesfully). Retrieved November, 27, 2013 from http://www.oia.ntust.edu.tw/files/14-101738060,r553-1.php

第2屆臺灣印尼高等教育論壇與臺灣高等 教育展成果豐碩 (The $2^{\text {nd }}$ Taiwan and Indonesia Higher Education Summit and the Taiwan Higher Education are Fruitful). Retrieved November 27, 2013 from http://www.edu.tw/pages/detail.aspx?Node $=1088 \&$ Page $=21404 \&$ wid $=409$ cab38-69fe4a61-ad3a-5d32a88deb5d\&Index $=1$

"Taiwan and Indonesia to Enhance Economic Relations", The President Post, March, 02, 2013. Retrieved April 2, 2013 from

http://www.thepresidentpost.com/2012/03/0 2/taiwan-and-indonesia-to-enhanceeconomic-relations/.

http://formmit.org/main-menu/aboutformmit.html

http://www.indexmundi.com/g/r.aspx?v $=21 \& \mathrm{t}=20$

http://perpita.freeinterchange.org/zh_tw Labout1-02.htm
http://data.worldbank.org/indicator/NY.GD

\section{P.PCAP.CD}

